\title{
RARß2 suppression in head and neck squamous cell carcinoma correlates with site, histology and age
}

\author{
JUDIT OLASZ ${ }^{1}$, ALÍZ JUHÁSZ ${ }^{1}$, ÉVA REMENÁR ${ }^{2}$, HELGA ENGI $^{3}$, \\ MIHÁLY BAK ${ }^{4}$, ORSOLYA CSUKA ${ }^{1}$ and MIKLÓS KÁSLER ${ }^{2}$ \\ Departments of ${ }^{1}$ Pathogenetics, ${ }^{2} \mathrm{Head}$ and Neck Surgery, National Institute of Oncology, Budapest; \\ ${ }^{3}$ Institute of Medical Microbiology and Immunobiology, Universtity of Szeged, Szeged; \\ ${ }^{4}$ Department of Cytopathology, National Institute of Oncology, Budapest, Hungary
}

Received January 25, 2007; Accepted March 8, 2007

\begin{abstract}
Retinoids as important growth and differentiation regulating agents have a potential role in the chemoprevention of head and neck squamous cell carcinoma (HNSCC). Despite the promising preclinical and early clinical findings, limitations of application are raised by intrinsic resistance acquired during carcinogenesis. Retinoic acid receptor B2 (RARB2) is one of the proximate mediators of retinoid signalling and its expression is often diminished in early stages of head and neck carcinogenesis. One form of retinoid resistance has been associated with the methylation-induced silencing of the RARß gene. We studied primary HNSCC samples of different anatomical sites in respect of methylation, expression and allelic loss of RAR 3 gene. A strong correlation $(\mathrm{p}<0.01)$ was found between hypermethylation and reduced expression of RAR 32 , however the allelic loss at 3p24, the locus of RARß, did not considerably influence its mRNA level. Hypopharynx tumors showed significantly lower hypermethylation $(\mathrm{p}<0.05)$ and higher mRNA expression levels of RARß2 compared to the tumors located at other sites of the head and neck. We could also provide evidence that poorly differentiated grade 3 tumors had significantly higher RARß2 expression and lower methylation levels $(p<0.05)$ than better differentiated grade 1 and grade 2 tumors. In addition, we found a good correlation between the methylation degree of the RARB2 promoter
\end{abstract}

Correspondence to: Dr Orsolya Csuka, National Institute of Oncology, Rath Gyorgy u. 7-9, 1122 Budapest, Hungary

E-mail:csuka@oncol.hu

Abbreviations: HNSCC, head and neck squamous cell carcinoma; RA, retinoic acid; RAR, retinoic acid receptor; RXR, retinoic X receptor; RARE, retinoic acid responsive element; UICC, International Union Against Cancer

Key words: retinoic acid, RARß2 expression, promoter hypermethylation, chemoprevention, retinoid resistance, HNSCC, squamous differentiation and the ages of patients. Collectively, our results suggest that evaluation of several factors such as tumor location, age, histology and methylation state of the RARß gene might contribute to the selection of patients for retinoid-based chemoprevention.

\section{Introduction}

Retinoids, natural and synthetic vitamin A analogues, play fundamental roles in regulation of cell growth, differentiation and apoptosis $(1,2)$. Retinoic acid (RA) can stimulate or inhibit growth and differentiation depending on the cell type (3). One of the main functions of vitamin A analogs is to prevent squamous differentiation with keratinization of nonkeratinizing epithelial tissues $(2,4)$. In animal models $(5,6)$ and cell culture systems (7-9) retinoids can suppress or reverse epithelial carcinogenesis. Several clinical studies demonstrated that retinoids can arrest or reverse the process of carcinogenesis in premalignant lesions of the skin, oral cavity, larynx and cervix and prevent the development of second primary tumors in patients with head and neck cancer, lung cancer and hepatocellular carcinoma (10). Nevertheless, the use of retinoids to prevent or treat human cancer has achieved only modest success, because of prevalent retinoid resistance $(11,12)$ and considerable toxicity of natural retinoids $(13,14)$

The nuclear retinoid receptors that mediate the actions of retinoids belong to the steroid/thyroid hormone receptor superfamily. Similar to other members of this family retinoid receptors are ligand-activated transcriptional regulators $(15,16)$. There are two types of nuclear retinoid receptors, RARs and RXRs (17). Each of the receptor types has three subtypes, $\alpha, \beta$ and $\gamma$. Various receptor isoforms exist through alternative splice sites and promoters. There are two major isoforms for RAR $\alpha$ and $R A R \gamma$ and four major isoforms for RARß (16). In the human RARß2 and RARß4 transcript variants have been identified in adult cells (16).

The RARs bind RA and 9-cis RA whereas the RXRs bind 9-cis RA but not RA. RXRs and RARs can form heterodimers and bind to specific retinoic acid response elements (RAREs) of target genes $(18,19)$. As nuclear retinoid receptors are the direct mediators of retinoid actions, changes in their expression 
may cause aberrations in the response of cells to retinoids. Especially, the supression of RARß2 expression has been found in various cancer cell types (20), including head and neck squamous cell carcinoma (HNSCC) cell lines $(21,22)$, premalignant oral lesions (23) and malignant head and neck tissues $(24,25)$. Consequently it is plausible that silenced RARß2 expression may be partially responsible for the limited clinical activity of classical retinoids (12). RARE has been identified in the RARß2 promoter (26), thus normally RARß2 can be induced by RA treatment; however, there are several cancer cell lines which are resistant to RA-mediated RARß2 induction $(27,28)$.

RARß has been mapped at chromosome band 3p24 which shows frequent loss in head and neck cancer $(29,30)$. It is therefore presumable that $\mathrm{LOH}$ at $3 \mathrm{p} 24$ may partly account for reduced expression of RARß2. In addition, recent studies have demonstrated that hypermethylation of $\mathrm{CpG}$ islands in RARß2 promoter correlates with transcriptional repression in several types of cancer, including HNSCC (31-33).

The aim of this study was to examine the genetic and epigenetic factors for RARß2 inactivation in head and neck cancer and identify patients who are more likely sensitive to retinoid therapy and chemoprevention.

\section{Materials and methods}

Patients and samples. Eighty-nine primary HNSCC and corresponding normal tissue samples of the oral cavity (34), oropharynx (15), hypopharynx (23) and larynx (17) were obtained from patients operated at the Head and Neck Surgery Department of the National Institute of Oncology, Budapest, between 1997 and 1999. UICC stages (34) and grades of tumors were defined (Table I). The sample collection was approved by the institutional ethics committee. All tissue samples were snap-frozen in liquid nitrogen and stored at $-80^{\circ} \mathrm{C}$ before DNA/RNA isolation.

DNA isolation. DNA was isolated from 89 cancer and corresponding normal tissue samples with the standard phenolchloroform extraction and ethanol precipitation following proteinase K (Sigma-Aldrich Co., St. Louis, MO, USA) digestion.

Loss of heterozygosity ( $\mathrm{LOH}$ ) analysis. Fluorescently labelled microsatellite markers were used for the loci D3S1283 and D3S1286 at the chromosome locus 3p24 (Table II) (52). Following PCR amplification of paired tumor and normal DNA samples, fragments were electrophoretically separated and detected by ABI-PRISM 3130 genetic analyzer (Applied Biosystems, Foster City, CA, USA ). LOH was stated when the relative peak height of one allele showed $>50 \%$ decrease in the tumor sample compared to the normal one in heterozygous samples. Samples homozygous for both alleles were assessed as non-informative.

Bisulfite modification. Sodium bisulfite conversion of the DNA from the 89 tumor samples and the matching normal samples was performed as described previously (35). Briefly, $2 \mu \mathrm{g}$ of genomic DNA was denatured in $0.3 \mathrm{M} \mathrm{NaOH}$, for $15 \mathrm{~min}$ at $37^{\circ} \mathrm{C}$, then incubated in dark at $55^{\circ} \mathrm{C}$ for $16 \mathrm{~h}$ in modification medium (2.6 $\mathrm{M} \mathrm{NaHSO}_{3}, 0.5 \mathrm{mM}$ hidroquinon, $0.1 \mathrm{M} \mathrm{NaOH})$. The converted DNA was purified with Wizard DNA clean-up system (Promega Co., Madison, WI, USA) and desulfonated $\left(0.3 \mathrm{M} \mathrm{NaOH}, 37^{\circ} \mathrm{C}, 10 \mathrm{~min}\right)$, then precipitated with ethanol and ammonium acetate and finally pellets were resolved in distilled water.

Methylation analysis. The methylation analysis was performed by the fluorescence-based real-time PCR assay, MethyLight as described previously $(36,37)$. Primer and probe sets (Table II) (53) were designed specifically for bisulfite converted DNA, a methylated set for the RARß gene and a reference set for $B$-actin, to normalize for input of modified DNA. Human sperm DNA was used as negative control and SssI methylase (New England Biolabs, Ipswich, MA, USA) treated human lymphocyte DNA was used as positive control. The percentage of fully methylated reference (PMR) at the RARB2 promoter was calculated by dividing the RARß2:ACTB ratio of the sample by the RARß2:ACTB ratio of the positive control and multiplying by 100 (37). The real-time PCR assay was performed by the use of ABI PRISM 7900 sequence detection system (Applied Biosystems). The PCR reaction mix contained $600 \mathrm{nM}$ of each primer, $200 \mathrm{nM}$ of TaqMan probe, $5 \mathrm{mM} \mathrm{MgCl}_{2}$ and $1 \mathrm{X}$ JumpStart Taq ReadyMix (Sigma-Aldrich Co.) in a final volume of $25 \mu 1$.

RNA isolation. Thirty-eight tumor samples (Table I) were available for isolation of intact RNA. Total RNA was isolated by MagNa Pure LC instrument applying the RNA isolation kit III (tissue) (Roche Diagnostics GmbH, Mannheim, Germany).

Quantitative RT-PCR. Two-step RT-PCRs were performed. RNA (250 ng) per sample was transcribed by M-MLV reverse transcriptase (Promega Co.). cDNA (1-1 $\mu 1)$ was used as template in the subsequent real-time PCRs; reactions were run in LightCycler instrument using LightCycler FastStart DNA Master SYBR Green I kit (Roche Diagnostics GmbH) according to the manufacturer's instructions. RARß2 mRNA expression level was determined in terms of percentage of glyceraldehyde-3-phosphate dehydrogenase (GAPDH) mRNA as endogenous control. The relative RARß2 expression values were calculated from standard curves drawn for RARß2 and GAPDH in each run. The primer sequences are indicated in Table II.

Statistical analysis. Associations of the LOH data with the pathological parameters (tumor, node, stage, grade) and also with the tumor sites were assessed using Chi-square tests. The methylation levels (PMR values) of normal and corresponding tumor samples were compared by the Wilcoxon matched-pairs signed-ranks test. The relative RARß2 expression and PMR values were related to the tumor locations and the pathological parameters above by the use of the Kruskal-Wallis test with Dunn's post test and Mann-Whitney test.

The relationship between the methylation level and RARß2 expression and correlation of each with the ages of patients were examined by performing Spearman tests. The above statistical tests were performed by GraphPad Instat 3 software. The results were considered statistically significant at $\mathrm{p} \leq 0.05$ significance level. 
Table I. Patient data: results of loss of heterozygosity and methylation analysis.

\begin{tabular}{|c|c|c|c|c|c|c|c|c|c|}
\hline Location & Patients & $T$ & $N$ & $S$ & Grade & $\begin{array}{l}\text { Age at } \\
\text { diagnosis } \\
\text { (years) }\end{array}$ & $\begin{array}{l}\text { Deletion } \\
\text { at } 3 \mathrm{p} 24\end{array}$ & $\begin{array}{c}\text { RARß2 } \\
\text { methylation } \\
(\text { PMR })\end{array}$ & $\begin{array}{c}\text { RARß2 } \\
\text { expression } \\
\text { (GAPDH\%) }\end{array}$ \\
\hline \multirow[t]{34}{*}{ Oral cavity } & 4 & 3 & 0 & 3 & 1 & 53 & $\mathrm{LOH}$ & 38.14 & NA \\
\hline & 22 & 2 & 2 & 4 & 1 & 48 & NI & 31.10 & NA \\
\hline & 42 & 3 & 0 & 3 & 1 & 68 & $\mathrm{LOH}$ & 11.98 & 3.89 \\
\hline & 52 & 2 & 0 & 2 & 1 & 70 & $\mathrm{LOH}$ & 18.77 & NA \\
\hline & 60 & 4 & 2 & 4 & 1 & 60 & - & 7.37 & 0.83 \\
\hline & 72 & 2 & 0 & 2 & 1 & 63 & - & 31.55 & 5.43 \\
\hline & 110 & 3 & 2 & 4 & 1 & 44 & $\mathrm{LOH}$ & 13.80 & 0.83 \\
\hline & 125 & 2 & 1 & 3 & 1 & 61 & - & 23.97 & 2.79 \\
\hline & 9 & 2 & 0 & 2 & 2 & 72 & - & 25.06 & NA \\
\hline & 18 & 3 & 2 & 4 & 2 & 59 & $\mathrm{LOH}$ & 34.41 & NA \\
\hline & 31 & 3 & 0 & 3 & 2 & 57 & $\mathrm{LOH}$ & 19.79 & NA \\
\hline & 49 & 2 & 0 & 2 & 2 & 59 & - & 12.71 & 0.82 \\
\hline & 50 & 2 & 0 & 2 & 2 & 57 & $\mathrm{LOH}$ & 1.70 & NA \\
\hline & 56 & 3 & 2 & 4 & 2 & 72 & - & 14.80 & NA \\
\hline & 57 & 4 & 1 & 4 & 2 & 48 & - & 6.67 & 0.24 \\
\hline & 59 & 3 & 2 & 4 & 2 & 62 & - & 3.83 & NA \\
\hline & 79 & 4 & 1 & 4 & 2 & 48 & - & 5.62 & NA \\
\hline & 83 & 2 & 2 & 4 & 2 & 66 & - & 17.72 & NA \\
\hline & 85 & 2 & 0 & 2 & 2 & 39 & - & 0.42 & 14.06 \\
\hline & 90 & 2 & 1 & 3 & 2 & 52 & - & 10.56 & NA \\
\hline & 109 & 3 & 1 & 3 & 2 & 39 & - & 64.83 & 1.23 \\
\hline & 120 & 4 & 2 & 4 & 2 & 56 & $\mathrm{LOH}$ & 38.40 & 0.00 \\
\hline & 123 & 2 & 0 & 2 & 2 & 47 & $\mathrm{LOH}$ & 26.59 & NA \\
\hline & 124 & 3 & 0 & 3 & 2 & 58 & $\mathrm{LOH}$ & 0.01 & 34.31 \\
\hline & 126 & 3 & 0 & 3 & 2 & 38 & $\mathrm{LOH}$ & 32.17 & NA \\
\hline & 131 & 2 & 0 & 2 & 2 & 52 & $\mathrm{LOH}$ & 2.40 & NA \\
\hline & 133 & 3 & 1 & 3 & 2 & 71 & - & 5.60 & NA \\
\hline & 61 & 2 & 1 & 3 & 2 & 55 & $\mathrm{LOH}$ & 3.42 & NA \\
\hline & 16 & 4 & 2 & 4 & 3 & 42 & $\mathrm{LOH}$ & 25.05 & NA \\
\hline & 33 & 3 & 0 & 3 & 3 & 47 & - & 2.68 & 3.32 \\
\hline & 97 & 3 & 0 & 3 & 3 & 64 & - & 15.12 & 2.04 \\
\hline & 101 & 4 & 0 & 4 & 3 & 62 & NI & 26.72 & 0.72 \\
\hline & 108 & 4 & 3 & 4 & 3 & 40 & - & 6.00 & 5.20 \\
\hline & 116 & 2 & 0 & 2 & 3 & 49 & NI & 0.99 & NA \\
\hline \multirow[t]{15}{*}{ Oropharynx } & 27 & 4 & 0 & 4 & 1 & 46 & $\mathrm{LOH}$ & 13.23 & 0.93 \\
\hline & 127 & 4 & 2 & 4 & 1 & 45 & $\mathrm{LOH}$ & 2.75 & NA \\
\hline & 38 & 3 & 1 & 3 & 2 & 61 & $\mathrm{LOH}$ & 10.30 & NA \\
\hline & 41 & 2 & 2 & 4 & 2 & 54 & - & 22.64 & NA \\
\hline & 148 & 4 & 2 & 4 & 2 & 57 & - & 23.97 & 0.00 \\
\hline & 70 & 3 & 1 & 3 & 2 & 55 & $\mathrm{LOH}$ & 29.93 & 3.29 \\
\hline & 105 & 4 & 1 & 4 & 2 & 61 & - & 23.60 & 0.00 \\
\hline & 114 & 3 & 2 & 4 & 2 & 42 & - & 8.13 & 1.55 \\
\hline & 119 & 4 & 2 & 4 & 2 & 47 & $\mathrm{LOH}$ & 22.54 & 0.00 \\
\hline & 128 & 2 & 2 & 4 & 2 & 61 & - & 43.96 & NA \\
\hline & 135 & 4 & 0 & 4 & 2 & 48 & $\mathrm{LOH}$ & 41.28 & NA \\
\hline & 39 & 4 & 1 & 4 & 3 & 44 & $\mathrm{LOH}$ & 2.19 & 4.76 \\
\hline & 73 & 2 & 0 & 2 & 3 & 38 & NI & 23.18 & NA \\
\hline & 92 & 1 & 1 & 3 & 3 & 59 & - & 31.54 & NA \\
\hline & 113 & 2 & 2 & 4 & 3 & 42 & - & 2.40 & 4.96 \\
\hline
\end{tabular}


Table I. Continued.

\begin{tabular}{|c|c|c|c|c|c|c|c|c|c|}
\hline Location & Patients & $T$ & $N$ & $S$ & Grade & $\begin{array}{l}\text { Age at } \\
\text { diagnosis } \\
\text { (years) }\end{array}$ & $\begin{array}{c}\text { Deletion } \\
\text { at 3p24 }\end{array}$ & $\begin{array}{c}\text { RARß2 } \\
\text { methylation } \\
(\mathrm{PMR})\end{array}$ & $\begin{array}{c}\text { RARß2 } \\
\text { expression } \\
(\text { GAPDH\%) }\end{array}$ \\
\hline \multirow[t]{23}{*}{ Hypopharynx } & 19 & 2 & 0 & 2 & 1 & 46 & $\mathrm{LOH}$ & 3.10 & NA \\
\hline & 62 & 4 & 0 & 4 & 1 & 74 & NI & 4.39 & 0.03 \\
\hline & 82 & 3 & 1 & 3 & 2 & 64 & $\mathrm{LOH}$ & 36.08 & NA \\
\hline & 3 & 3 & 2 & 4 & 2 & 45 & $\mathrm{LOH}$ & 7.47 & NA \\
\hline & 8 & 3 & 1 & 3 & 2 & 50 & - & 16.93 & NA \\
\hline & 25 & 3 & 1 & 3 & 2 & 48 & - & 13.38 & NA \\
\hline & 54 & 3 & 1 & 3 & 2 & 44 & - & 0.49 & NA \\
\hline & 84 & 4 & 2 & 4 & 2 & 44 & $\mathrm{LOH}$ & 0.00 & 0.16 \\
\hline & 98 & 4 & 2 & 4 & 2 & 49 & $\mathrm{LOH}$ & 9.96 & 0.27 \\
\hline & 112 & 3 & 0 & 3 & 2 & 46 & - & 3.16 & 14.04 \\
\hline & 134 & 3 & 0 & 3 & 2 & 67 & - & 7.40 & NA \\
\hline & 5 & 3 & 2 & 4 & 3 & 45 & $\mathrm{LOH}$ & 0.00 & NA \\
\hline & 43 & 1 & 2 & 4 & 3 & 57 & - & 3.44 & 5.44 \\
\hline & 51 & 4 & 1 & 4 & 3 & 56 & - & 4.74 & NA \\
\hline & 55 & 3 & 2 & 4 & 3 & 47 & - & 5.41 & 4.24 \\
\hline & 104 & 3 & 3 & 4 & 3 & 44 & $\mathrm{LOH}$ & 6.66 & 14.66 \\
\hline & 106 & 4 & 2 & 4 & 3 & 45 & $\mathrm{LOH}$ & 1.80 & 45.00 \\
\hline & 117 & 3 & 2 & 4 & 3 & 56 & - & 1.98 & 28.89 \\
\hline & 121 & 2 & 2 & 4 & 3 & 45 & $\mathrm{LOH}$ & 8.13 & NA \\
\hline & 129 & 3 & 2 & 4 & 3 & 39 & - & 8.39 & NA \\
\hline & 143 & 4 & 2 & 4 & 3 & 52 & - & 2.30 & 16.01 \\
\hline & 150 & 3 & 2 & 4 & 3 & 74 & - & 5.77 & NA \\
\hline & 6 & 2 & 0 & 2 & 3 & 52 & $\mathrm{LOH}$ & 3.33 & NA \\
\hline \multirow[t]{17}{*}{ Larynx } & 44 & 1 & 0 & 1 & 1 & 49 & $\mathrm{LOH}$ & 31.28 & NA \\
\hline & 76 & 3 & 2 & 4 & 1 & 59 & $\mathrm{LOH}$ & 100.00 & 2.03 \\
\hline & 87 & 3 & 0 & 3 & 1 & 46 & - & 6.40 & NA \\
\hline & 32 & 3 & 0 & 3 & 2 & 65 & - & 8.40 & NA \\
\hline & 34 & 3 & 0 & 3 & 2 & 46 & - & 7.40 & NA \\
\hline & 58 & 4 & 0 & 4 & 2 & 63 & $\mathrm{LOH}$ & 13.39 & 1.31 \\
\hline & 80 & 3 & 2 & 4 & 2 & 70 & $\mathrm{LOH}$ & 4.08 & NA \\
\hline & 81 & 3 & 2 & 4 & 2 & 50 & - & 17.14 & NA \\
\hline & 95 & 3 & 2 & 4 & 2 & 58 & - & 26.44 & 1.68 \\
\hline & 107 & 3 & 0 & 3 & 2 & 59 & - & 16.43 & NA \\
\hline & 122 & 3 & 0 & 3 & 2 & 47 & - & 58.60 & 0 \\
\hline & 149 & 3 & 1 & 3 & 2 & 49 & - & 21.10 & 0 \\
\hline & 12 & 3 & 0 & 3 & 3 & 65 & $\mathrm{LOH}$ & 14.43 & NA \\
\hline & 21 & 4 & 0 & 4 & 3 & 42 & - & 10.00 & NA \\
\hline & 37 & 4 & 0 & 4 & 3 & 54 & $\mathrm{LOH}$ & 5.60 & NA \\
\hline & 71 & 4 & 2 & 4 & 3 & 48 & - & 0.69 & NA \\
\hline & 94 & 4 & 0 & 4 & 3 & 52 & $\mathrm{LOH}$ & 4.93 & NA \\
\hline
\end{tabular}

T-N-S, tumor size - lymph node metastases - stage according to the UICC classification; LOH, loss of heterozygosity; NI, not informative; NA, not available; PMR, percentage of methylated reference.

\section{Results}

Loss of heterozygosity analysis. We found loss of heterozygosity in 38 of 84 informative cases $(45.2 \%)$ for at least one marker of $3 \mathrm{p} 24$ band (Table I). Oropharynx tumors showed the highest incidence of $\mathrm{LOH}(50 \%)$, but the differences were not significant among different location groups. There were no significant associations between allelic loss and clinicopathological parameters such as tumor size, lymph node metastasis or stage. It can be noted that the highest frequency of $\mathrm{LOH}$ 
A

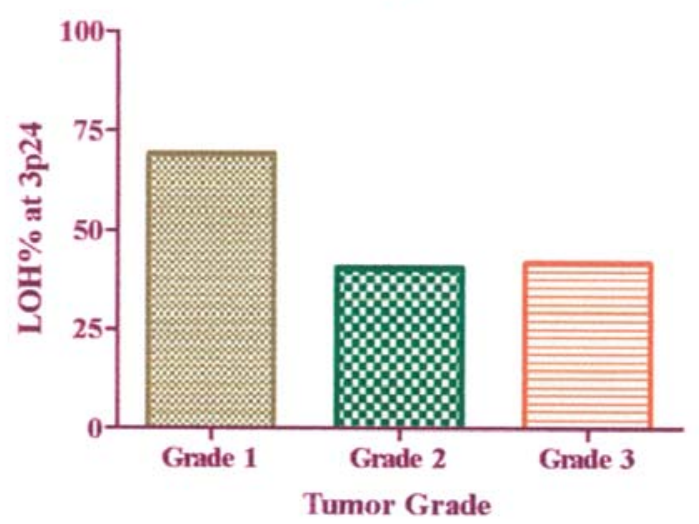

B

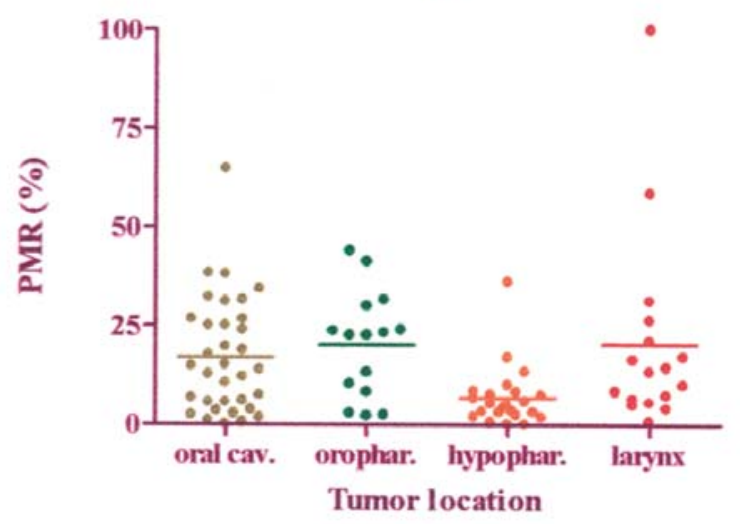

C

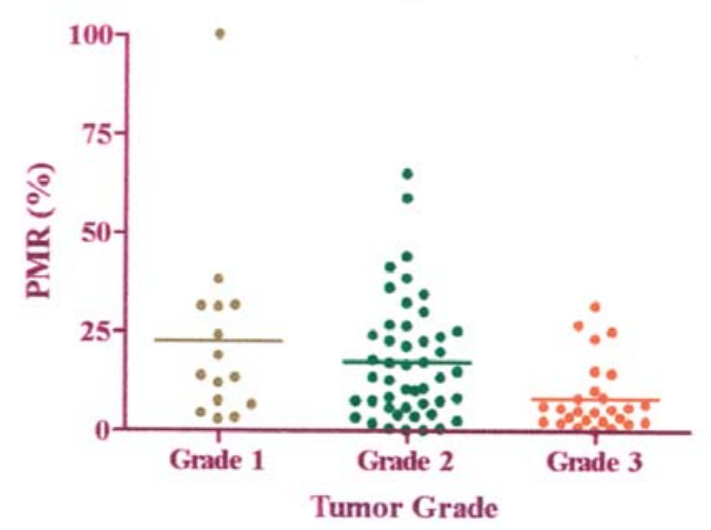

D

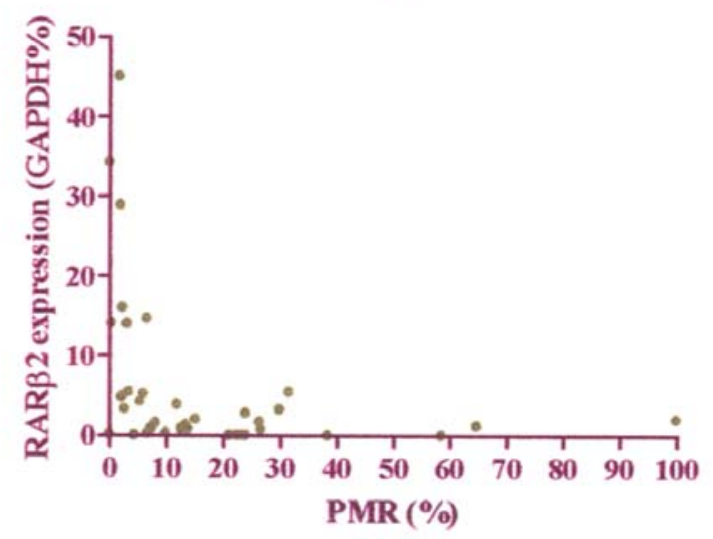

E

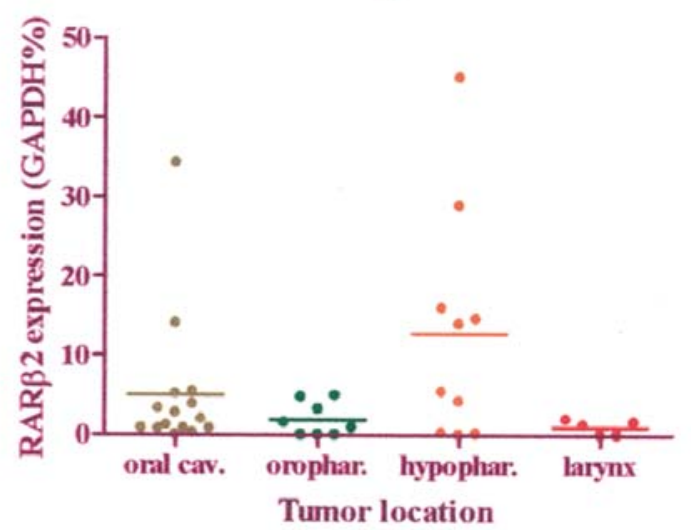

F

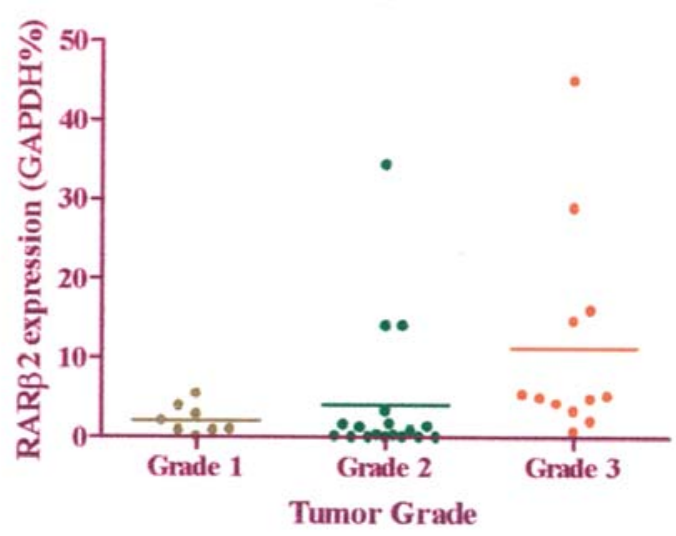

Figure 1. Associations of allelic loss, promoter methylation and RARß2 expression with the differentiation grade and location of the tumor. (A) Loss of heterozygosity at locus 3p24 in distinctly differentiated tumors. (B) Methylation degree of RARß2 promoter in tumors of different sites. (C) Methylation degree of RARß2 promoter in tumors of different grades. (D) RARß2 mRNA expression in the function of promoter methylation. (E) RARß2 mRNA levels in tumors of different locations. (F) RARß2 mRNA levels in tumors of different grades. LOH, loss of heterozygosity; PMR, percentage of methylated reference; GAPDH, glyceraldehyde-3-phosphate dehydrogenase. Mean values are indicated by horizontal lines.

was seen in grade 1 tumors $(69.2 \%)$ in contrast to grade 2 and 3 tumors ( $40.4 \%$ and $41.7 \%$, respectively); however, the difference was not quite significant $(\mathrm{p}=0.07)$ (Fig. 1A). No correlation was seen between $\mathrm{LOH}$ and the ages of patients.

Methylation analysis. The quantitative MethyLight analysis of matched tumor - normal sample pairs revealed that the tumor samples had significantly higher methylation levels than their normal counterparts $(\mathrm{p}<0.01)$. The average methylation level of RAR 32 promoter was found to be the lowest in the hypopharyngeal tumors (Fig. 1B) and these had a statistically similar mean methylation value as normal samples $(p=0.59)$. The tumors of oral cavity, oropharynx and larynx had significantly higher methylation degrees as 
Table II. Primer and probe sets applied for $\mathrm{LOH}$, methylation, and expression analyses.

\begin{tabular}{llll}
\hline Analysis & \multicolumn{1}{c}{ Target (ref.) } & \multicolumn{1}{c}{ Forward primer (5'-3') } & \multicolumn{1}{c}{ Reverse primer (5'-3') } \\
\hline LOH & D3S1286(52) & FAM-GCAGTGACTTCAGAGGGGC & ATTGACGGGGCTAGGGC \\
& $D 3 S 1283(52)$ & HEX-GGCAGTACCACCTGTAGAAATG & GAGTAACAGAGGCATCGTGTATTC \\
RT-PCR & $R A R \_2($ NM_000965) & GGGAGGAAGTGGAGATGG & ATGCTTCAGTGGATTGACC \\
& GAPDH (NM_002046) & TGAACCATGAGAAGTATGACAACA & AGTCCTTCCACGATACCAAA \\
MethyLight & $R A R \_2(X 56849)$ & TGAGGATTGGGATGTCGAGAA & CCTTCCGAATACGTTCCGAAT \\
& TaqMan probe (5'-3') & 6FAM-CGACGATACCCAAACAAACCCTACTCGAAT-TAMRA \\
& ACTB (Y00474) (53) & TGGTGATGGAGGAGGTTTAGTAAGT & AACCAATAAAACCTACTCCTCCCTTAA \\
& TaqMan probe (5'-3') & 6FAM-ACCACCACCCAACACACAATAACAAACACA-TAMRA \\
\hline
\end{tabular}

compared to hypopharynx tumors $(\mathrm{p}<0.05)$. The largest difference was observed between the mean PMR (percentage of methylated reference) values of oropharynx and hypopharynx samples $(\mathrm{p}<0.01)$ (Fig. 1B). The methylation data of oral cavity, oropharynx and larynx did not vary significantly from each other. The promoter methylation status did not correlate with the clinicopathological parameters, but was found to be related to the histological grade. Although grade 1 and 2 tumors did not differ statistically, the tumors had significantly higher methylation levels than grade 3 tumors (Dunn's $\mathrm{p}<0.05, \mathrm{p}<0.05$ ) (Fig. $1 C)$. The grade 3 group did not differ considerably from the normal samples $(\mathrm{p}=0.34)$. Spearman test resulted in a positive correlation between methylation levels and the age of the patients $(\mathrm{r}=0.22 ; \mathrm{p}=0.04)$.

RARß2 expression analysis. RARß2 mRNA expression had very strong negative correlation with methylation level $(\mathrm{r}=-0.55 ; \mathrm{p}=0.0003)$ (Fig. 1D), but showed independence from loss of heterozygosity at $3 \mathrm{p} 24$. In line with methylation results, hypopharynx tumors were observed to have considerably higher RARß expression levels than oropharynx $(p=0.04)$ and larynx $(p=0.06)$ and moderately higher expression than oral tumors $(\mathrm{p}=0.2)$ (Fig. 1E). Grade 1 and 2 samples expressed significantly less RARß2 mRNA than grade 3 tumors ( $\mathrm{p}<0.05$ and $\mathrm{p}<0.001$, respectively) (Fig. 1F), whereas grade 1 and 2 samples did not differ considerably in this respect. Similar to $\mathrm{LOH}$ and methylation results, expression levels proved to be independent from clinicopathological characteristics. We could not demonstrate a significant relationship between age and expression level.

\section{Discussion}

Retinoids are able to reverse carcinogenesis through multiple mechanisms including the modulation of epithelial differentiation and proliferation by regulating gene expression. This regulation is mediated by nuclear retinoid receptors. One of these receptors is the retinoic acid receptor- 32 (RARß2), expression of which is suppressed in early stages of head and neck carcinogenesis $(24,25)$. The restoration of RARß2 expression has been shown to be associated with clinical response, suggesting it as a marker in chemoprevention trials (24).
We investigated the role of allelic loss and epigenetic silencing of RARß2 expression in tumors located at different sites of the head and neck region and we also examined the associations of these molecular features with clinico- and histopathological parameters.

In line with other studies (33) we found a frequent allelic loss $(45.2 \%)$ at 3 p24 region, where RARB is located. It is of interest that loss of heterozygosity did not show significant correlation with either the clinical stage or RARß2 mRNA expression. These findings are in line with observations in breast carcinoma (38) and esophageal cancer (39) where other groups also reported no correlation between LOH at 3p24 and RARß2 expression. It can be due to the retained allele, which remains inducible by retinoids if otherwise intact. In contrast to that, the methylation degree of RARß2 promoter was negatively correlated with the RARß2 mRNA level $(\mathrm{r}=-0.55 ; \mathrm{p}<0.01)$, suggesting hypermethylation as the main reason for RARß2 suppression. Significantly higher methylation levels were detected in tumor samples than their normal counterparts $(\mathrm{p}<0.01)$. RARß2 methylation was found rather frequently by others in normal squamous epithelium (40) and resection margins (41). It is likely because RARß2 methylation is an early event in carcinogenesis, and resection margins frequently have such an epigenetic alteration owing to field cancerization. Although RARß2 methylation occurs in normal mucosa, the reverse quantitative correlation of RARß2 methylation and mRNA expression suggests its higher expression level in normal tissue. Similar to loss of heterozygosity, promoter hypermethylation and RARB2 expression were not correlated with clinicopathological parameters such as tumor size and lymph node involvement. These results support that $\mathrm{LOH}$ and epigenetic alterations at the locus of RARß are both early events and independent prognostic factors in the carcinogenesis of the head and neck region.

Promoter methylation and RAR 32 mRNA levels proved to have significant correlation with the histological grade (Dunn's $\mathrm{p}<0.05$ in both cases). Namely, grade 3 tumors had lower methylation and higher expression levels of RARß2 than more differentiated tumors. Similar correlation was found between grade and methylation status by Liu et al in esophageal squamous carcinoma (42). Unfortunately, differentiation grade is not accurate in reflecting the agressiveness of HNSCC (43). Prognosis is influenced by many factors, such as tumor 
size, site, vascularity, lymphatic drainage, host immune response, age, sex, nutritional and performance status (44). According to the traditional grading criteria developed by Broders (45) keratinization is the major determinant of grade. Better differentiated tumors that produce more keratin are thought to be less likely to metastasize (46). Nuclear receptors for retinoic acid and thyroid hormone regulate transcription of keratin genes (46). In squamous carcinoma cells of head and neck retinoids were found to inhibit squamous cell differentiation and suppress keratin expression (e.g. K1, K5) by the implication of RARß2 (47). Accordingly, expression of RARß2 is inversely related to squamous cell differentiation and cell growth (48). We first found correlation between expression status and histological grade in HNSCC tumors, as it was suspected from the cell culture experiments $(47,48)$. Moreover, the methylation degree of grade 3 tumors did not differ significantly from normal samples $(\mathrm{p}=0.34)$. Considering these facts, grade 3 tumors can be predicted to express higher levels of RARß2 and therefore seem more sensitive to retinoid treatment.

Comparing tumors of different locations, we found that the methylation of RARß2 promoter was significantly lower in hypopharynx tumors than tumors of the oral cavity, oropharynx and larynx $(\mathrm{p}<0.05 ; \mathrm{p}<0.01 ; \mathrm{p}<0.05)$, but it was statistically indistinguishable from the normal samples $(\mathrm{p}=0.59)$. Concordant results were determined for mRNA expression. RARß2 mRNA levels were significantly higher in hypopharynx tumors compared with oropharyngeal and laryngeal tumors $(p<0.05 ; p=0.055)$, although the differrence was not found significant in the case of oral tumors $(\mathrm{p}=0.22)$, probably because of the limited sample sizes. It should be noted that these results may be related to the fact that grade 3 tumors were the most frequent in the hypopharyngeal group, though the Chi-square test for independence did not result in significant association. Based on this, it is also presumable that the carcinogenesis of the hypopharyngeal region follows different pathways in some aspects compared to the other sites of the head and neck. We have not found any similar or supportive findings in the published literature yet, therefore further in-depth investigations are needed.

We also revealed a positive correlation between the methylation degree of the RARß gene and the ages of the patients $(\mathrm{r}=0.22 ; \mathrm{p}=0.04)$. We can suppose that continous exposure of the upper aerodigestive tract to carcinogens leads to gradually expanding methylation of several gene promoters, such as RARß2. It is also supported by the findings of Zöchbauer-Müller and co-workers, who showed aberrant methylation of multiple genes in the upper aerodigestive epithelium of heavy smokers (49).

Being a mediator of RA response, RARß2 can serve as a marker in chemoprevention. Our results suggest that promoter hypermethylation is the main reason for RAR 32 suppression, which is a frequent event in head and neck carcinogenesis. Thus, methylation of RARß gene can be not only a marker for early carcinogenesis, but also a putative indicator for resistance to retinoids. Sensitive methylation-specific PCR-based techniques enable to detect DNA methylation even in serum, and saliva $(50,51)$. On one hand, the success of retinoid therapy, could be improved by the application of a new generation of receptor selective, synthetic retinoids and the use of combination regimens including demethylating agents (11). On the other hand, multistep evaluation of several factors, including tumor location, age, histology and methylation state of RARß2 promoter may contribute to the selection of patients promising for retinoid-based therapy or post-operative chemoprevention. These considerations support the idea that grade 3 , hypopharynx tumors of younger patients may have better results in retinoid therapy.

Nevertheless, the high frequency of RAR 32 repression has not excluded the presence of other potential mechanisms of retinoid resistance (11). Further investigations are still needed to reveal other (possibly downstream) targets of retinoid signalling which might play roles in resistance mechanisms.

\section{Acknowledgements}

This study was supported by the National Research and Development Program NKFP1-00024/2005: Improvement of cancer management by genomic approaches.

\section{References}

1. Sporn MB and Roberts AB: Role of retinoids in differentiation and carcinogenesis. J Natl Cancer Inst 73: 1381-1387, 1984.

2. De Luca LM: Retinoids and their receptors in differentiation, embryogenesis, and neoplasia. FASEB J 5: 2924-2933, 1991.

3. Glass CK, Devary OV and Rosenfeld MG: Multiple cell typespecific proteins differentially regulate target sequence recognition by the alpha retinoic acid receptor. Cell 63: 729-738, 1990.

4. Lotan R: Squamous cell differentiation markers in normal, premalignant, and malignant epithelium: effects of retinoids. J Cell Biochem 17 (Suppl): F167-F174, 1993.

5. Moon RC, Mehta RG and Rao KV: Retinoids and cancer in experimental animals. In: The Retinoids. Sporn MB, Roberts AB and Goodman DS (eds). Raven Press, New York, pp573-595, 1994.

6. Shklar G and Schwartz J: Oral cancer inhibition by micronutrients. The experimental basis for clinical trials. Eur J Cancer B Oral Oncol 29: B9-B16, 1993.

7. Simeone AM and Tari AM: How retinoids regulate breast cancer cell proliferation and apoptosis. Cell Mol Life Sci 61: 1475-1484, 2004.

8. Briviba K, Schnabele K, Schwertle E, Blockhaus M and Rechkemmer G: Beta-carotene inhibits growth of human colon carcinoma cells in vitro by induction of apoptosis. Biol Chem 382: 1663-1668, 2001.

9. Jetten AM, Kim JS, Sacks PG, Rearick JI, Lotan D, Hong WK and Lotan R: Inhibition of growth and squamous-cell differentiation markers in cultured human head and neck squamous carcinoma cells by beta-all-trans retinoic acid. Int J Cancer 45: 195-202, 1990.

10. Sun SY and Lotan R: Retinoids and their receptors in cancer development and chemoprevention. Crit Rev Oncol Hematol 41: 41-55, 2002.

11. Freemantle SJ, Spinella MJ and Dmitrovsky E: Retinoids in cancer therapy and chemoprevention: promise meets resistance. Oncogene 22: 7305-7315, 2003.

12. Freemantle SJ, Dragnev KH and Dmitrovsky E: The retinoic acid paradox in cancer chemoprevention. J Natl Cancer Inst 98: 426-427, 2006.

13. La Vecchia C, Tavani A and Garattini S: Adverse effects of preventive therapy in humans. IARC Sci Publ 139:135-142, 1996.

14. Benner SE, Pajak TF, Stetz J, Lippman SM, Hong WK, Schantz SP, Gallagher MJ and Shenouda G: Toxicity of isotretinoin in a chemoprevention trial to prevent second primary tumors following head and neck cancer. J Natl Cancer Inst 86: 1799-1801, 1994.

15. Giguere V, Ong ES, Segui P and Evans RM: Identification of a receptor for the morphogen retinoic acid. Nature 330: 624-629, 1987. 
16. Chambon P: A decade of molecular biology of retinoic acid receptors. FASEB J 10: 940-954, 1996.

17. Mangelsdorf DJ, Umesono K and Evans RM: The retinoid receptors. In: The Retinoids. Sporn $\mathrm{MB}$, Roberts $\mathrm{AB}$ and Goodman DS (eds). 2nd edition. Raven Press, New York, pp319-349, 1994

18. Allenby G, Janocha R, Kazmer S, Speck J, Grippo JF and Levin AA: Binding of 9-cis-retinoic acid and all-trans-retinoic acid to retinoic acid receptors alpha, beta, and gamma. Retinoic acid receptor gamma binds all-trans-retinoic acid preferentially over 9-cis-retinoic acid. J Biol Chem 269: 16689-16695, 1994.

19. Chambon P: The retinoid signaling pathway: molecular and genetic analyses. Semin Cell Biol 5: 115-125, 1994.

20. de The H: Altered retinoic acid receptors. FASEB J 10: 955-960, 1996.

21. Hu L, Crowe DL, Rheinwald JG, Chambon P and Gudas LJ: Abnormal expression of retinoic acid receptors and keratin 19 by human oral and epidermal squamous cell carcinoma cell lines. Cancer Res 51: 3972-3981, 1991.

22. Zou CP, Clifford JL, Xu XC, Sacks PG, Chambon P, Hong WK and Lotan R: Modulation by retinoic acid (RA) of squamous cell differentiation, cellular RA-binding proteins, and nuclear RA receptors in human head and neck squamous cell carcinoma cell lines. Cancer Res 54: 5479-5487, 1994.

23. Lotan R, Xu XC, Lippman SM, Ro JY, Lee JS, Lee JJ and Hong WK: Suppression of retinoic acid receptor-beta in premalignant oral lesions and its up-regulation by isotretinoin. N Engl J Med 332: 1405-1410, 1995.

24. Xu XC, Ro JY, Lee JS, Shin DM, Hong WK and Lotan R: Differential expression of nuclear retinoid receptors in normal, premalignant, and malignant head and neck tissues. Cancer Res 54: 3580-3587, 1994.

25. Castillo L, Milano G, Santini J, Demard F and Pierrefite V: Analysis of retinoic acid receptor beta expression in normal and malignant laryngeal mucosa by a sensitive and routine applicable reverse transcription-polymerase chain reaction enzyme-linked immunosorbent assay method. Clin Cancer Res 3: 2137-2142, 1997.

26. de The H, Vivanco-Ruiz MM, Tiollais P, Stunnenberg H and Dejean A: Identification of a retinoic acid responsive element in the retinoic acid receptor beta gene. Nature 343: 177-180, 1990.

27. Geradts J, Chen JY, Russell EK, Yankaskas JR, Nieves L and Minna JD: Human lung cancer cell lines exhibit resistance to retinoic acid treatment. Cell Growth Differ 4: 799-809, 1993.

28. Zou CP, Youssef EM, Zou CC, Carey TE and Lotan R: Differential effects of chromosome $3 p$ deletion on the expression of the putative tumor suppressor RAR beta and on retinoid resistance in human squamous carcinoma cells. Oncogene 20: 6820-6827, 2001

29. Partridge M, Emilion G and Langdon JD: $\mathrm{LOH}$ at $3 p$ correlates with a poor survival in oral squamous cell carcinoma. Br J Cancer 73: 366-371, 1996.

30. Grati FR, Sirchia SM, Garagiola I, Sironi E, Galioto S, Rossella F, Serafini P, Dulcetti F, Bozzetti A, Brusati R and Simoni G: Losses of heterozygosity in oral and oropharyngeal epithelial carcinomas. Cancer Genet Cytogenet 118: 57-61, 2000.

31. Widschwendter M, Berger J, Hermann M, Muller HM, Amberger A, Zeschnigk M, Widschwendter A, Abendstein B, Zeimet AG, Daxenbichler G and Marth C: Methylation and silencing of the retinoic acid receptor-beta2 gene in breast cancer. J Natl Cancer Inst 92: 826-832, 2000.

32. Virmani AK, Rathi A, Zochbauer-Muller S, Sacchi N, Fukuyama Y, Bryant D, Maitra A, Heda S, Fong KM, Thunnissen F, Minna JD and Gazdar AF: Promoter methylation and silencing of the retinoic acid receptor-beta gene in lung carcinomas. J Natl Cancer Inst 92: 1303-1307, 2000.

33. Youssef EM, Lotan D, Issa JP, Wakasa K, Fan YH, Mao L, Hassan K, Feng L, Lee JJ, Lippman SM, Hong WK and Lotan R: Hypermethylation of the retinoic acid receptor-beta(2) gene in head and neck carcinogenesis. Clin Cancer Res 10: 1733-1742, 2004.

34. Sobin L and Wittekind C: Head and neck tumors. TNM classification of malignant tumors. In: International Union Against Cancer (UICC). 6th edition. Wiley, New York, pp19-42, 2002 .
35. Frommer M, McDonald LE, Millar DS, Collis CM, Watt F, Grigg GW, Molloy PL and Paul CL: A genomic sequencing protocol that yields a positive display of 5-methylcytosine residues in individual DNA strands. Proc Natl Acad Sci USA 89: 1827-1831, 1992.

36. Eads CA, Danenberg KD, Kawakami K, Saltz LB, Blake C, Shibata D, Danenberg PV and Laird PW: MethyLight: a highthroughput assay to measure DNA methylation. Nucleic Acids Res 28: E32, 2000.

37. Trinh BN, Long TI and Laird PW: DNA methylation analysis by MethyLight technology. Methods 25: 456-462, 2001.

38. Yang Q, Yoshimura G, Nakamura M, Nakamura Y, Shan L, Suzuma T, Tamaki T, Umemura T, Mori I and Kakudo K: Allelic loss of chromosome 3 p24 correlates with tumor progression rather than with retinoic acid receptor beta2 expression in breast carcinoma. Breast Cancer Res Treat 70: 39-45, 2001.

39. Qiu H, Lotan R, Lippman SM and Xu XC: Lack of correlation between expression of retinoic acid receptor-beta and loss of heterozygosity on chromosome band 3p24 in esophageal cancer. Genes Chromosomes Cancer 28: 196-202, 2000.

40. Maruya S, Issa JP, Weber RS, Rosenthal DI, Haviland JC, Lotan R and El-Naggar AK: Differential methylation status of tumor-associated genes in head and neck squamous carcinoma: Incidence and potential implications. Clin Cancer Res 10: 3825-3830, 2004.

41. Shaw RJ, Liloglou T, Rogers SN, Brown JS, Vaughan ED, Lowe D, Field JK and Risk JM: Promoter methylation of P16, RARbeta, E-cadherin, cyclin A1 and cytoglobin in oral cancer: quantitative evaluation using pyrosequencing. Br J Cancer 94: 561-568, 2006.

42. Liu Z, Zhang L, Ding F, Li J, Guo M, Li W, Wang Y, Yu Z, Zhan Q, Wu M and Liu Z: 5-Aza-2'-deoxycytidine induces retinoic acid receptor-beta(2) demethylation and growth inhibition in esophageal squamous carcinoma cells. Cancer Lett 230: 271-283, 2005 .

43. Crissman JD, Liu WY, Gluckman JL and Cummings G: Prognostic value of histopathologic parameters in squamous cell carcinoma of the oropharynx. Cancer 54: 2995-3001, 1984.

44. Diaz EM, Sturgis EM, Laramore GE, Sabichi AL, Lippman SM and Clayman G: Neoplasms of the head and neck. Pathologic assessment. In: Cancer Medicine. Kufe DW, Pollock RE, Weichselbaum RR, Bast RC, et al (eds). BC Decker Inc., Hamilton, pp1561-1562, 2003

45. Broders AC: The microscopic grading of cancer. Surg Clin North Am 21: 947, 1941.

46. Tomic M, Jiang CK, Epstein HS, Freedberg IM, Samuels HH and Blumenberg M: Nuclear receptors for retinoic acid and thyroid hormone regulate transcription of keratin genes. Cell Regul 1: 965-973, 1990.

47. Lotan R: Retinoids and their receptors in modulation of differentiation, development, and prevention of head and neck cancers. Anticancer Res 16: 2415-2419, 1996.

48. Zou CP, Hong WK and Lotan R: Expression of retinoic acid receptor beta is associated with inhibition of keratinization in human head and neck squamous carcinoma cells. Differentiation 64: 123-132, 1999.

49. Zöchbauer-Müller S, Lam S, Toyooka S, Virmani AK, Toyooka KO, Seidl S, Minna JD and Gazdar AF: Aberrant methylation of multiple genes in the upper aerodigestive tract epithelium of heavy smokers. Int J Cancer 107: 612-616, 2003.

50. Sanchez-Cespedes M, Esteller M, Wu L, Nawroz-Danish H, Yoo GH, Koch WM, Jen J, Herman JG and Sidransky D: Gene promoter hypermethylation in tumors and serum of head and neck cancer patients. Cancer Res 60: 892-895, 2000.

51. Rosas SL, Koch W, da Costa Carvalho MG, Wu L, Califano J, Westra W, Jen J and Sidransky D: Promoter hypermethylation patterns of p16, O6-methylguanine-DNA-methyltransferase, and death-associated protein kinase in tumors and saliva of head and neck cancer patients. Cancer Res 61: 939-942, 2001.

52. Human Genome Database (www.gdb.org)

53. Eads CA, Lord RV, Wickramasinghe K, Long TI, Kurumboor SK, Bernstein L, Peters JH, DeMeester SR, DeMeester TR, Skinner KA and Laird PW: Epigenetic patterns in the progression of esophageal adenocarcinoma. Cancer Res 61: 3410-3418, 2001. 